or the past five years, ARL members have responded to the annual “Ten-Minute Survey"- three questions about budget allocations at the beginning of the fiscal year. Response rates have been fairly high, signifying great interest in understanding how ARL libraries are faring since the 2008 economic downturn. The most recent survey covering fiscal year 2012-2013 was administered in late 2012 and, in "ARL Library Budgets after the Great Recession, 2011-13," Charles B. Lowry, retired ARL executive director, analyzes the survey results for the past two fiscal years. Lowry discusses the data from both years separately as well as reporting on the 88 libraries that responded for both fiscal years, noting upward and downward trends in allocations.

Karla L. Strieb, Ohio State University, and Julia C. Blixrud, ARL, present their findings from the 2012 survey of ARL member libraries about their subscriptions to journal collections from large publishers in “The State of Large-Publisher Bundles in 2012." The 2012 survey builds on data collected in 2002 and 2005 and highlights a number of trends over time. Two examples include the percentage of contracts licensed via consortium and the shift from print to electronic-only subscriptions. Strieb and Blixrud note that pricing models and license terms, consortial agreements, and the conversion from print to electronic subscriptions remain key issues over the past 10 years.

In the last article in this issue of RLI, "Evolving Models of Reference Staffing at the University of Kansas [KU] Libraries," Frances Devlin and John Stratton describe steps taken at KU to address the changing roles of librarians and the impact on traditional service desks. With librarians spending more time in leadership roles in areas of open access, copyright consultancy, data-services management, and classroom teaching, a new service model was needed. The KU model for staffing the reference desk has evolved into a formal training and development program for research specialists.

—Sue Baughman, editor

\section{In This Issue}

\section{ARL Library Budgets after the}

Great Recession, 2011-13.

The State of Large-Publisher

Bundles in 2012 13

Evolving Models of Reference

Staffing at the University of

Kansas Libraries. 


\section{ARL Library Budgets after the Great Recession, 2011-13}

\section{Charles B. Lowry, Professor Emeritus, University of Maryland College Park}

ince 2008, ARL has collected annually member data on budget allocations at the beginning of the fiscal year. At first these efforts were motivated by the desire to understand what was happening at the beginning of the "great recession" in 2008. As time passed, it became clear that there was a broad interest, not only among members, but also in higher education and the publishing community about these initial budgets as predictors of the lagging indicator of expenditures collected annually for the ARL Statistics. ${ }^{1}$ In simplest terms, members were asked, "How much money did you get, not how much did you spend?" The survey instrument was refined progressively for three years and in fiscal year 2011-12 was stabilized. The current version, referred to by the shorthand the "Ten-Minute Survey," has been simplified and pared down to three essential questions that capture the gestalt of a library's budget. ${ }^{2}$ While lacking the detailed precision of a lengthier survey, the resulting data are sufficient to reveal the initial fiscal state of budgets, and to a significant degree to project near-term trends that do not show up in the ARL Statistics for several years.

The key question remains—when will the budgets of ARL members recover to pre-2008 levels? The National Association of State Budget Officers gives mixed reviews to recovery in state budgets for 2013, noting that in 36 states $\mathrm{K}-12$ education received increased spending, whereas higher education continued to experience cuts. The general picture is a bit sobering. "Even with revenue growth, state budgets are still facing pressure, with 24 states enacting lower spending levels in fiscal 2013 than in fiscal 2008. In nominal terms aggregate general fund expenditure levels are also still below the pre-recession peak of $\$ 687.3$ billion. Aggregate spending levels would need to be at $\$ 735$ billion, or 7.9 percent higher to remain equivalent with real 2008 spending levels." As this article shows, budgets of ARL member libraries generally do not meet this demand. ${ }^{3}$

The first three years of the "Ten-Minute Survey" were reported in two publications. ${ }^{4}$ This article captures two fiscal years FY2011-2012 (hereafter FY11-12) and FY2012-2013 (hereafter FY12-13). The article discusses the data from both years separately, but also provides a deeper view by looking at the 88 libraries that reported in both years to examine how they fared from one year to the next. As the recession abates and a recovery (however slow) emerges, this analysis attempts to answer the key question, "Do the data from the last two fiscal years indicate a trend that ARL member library budgets are on the mend?"

The "Ten-Minute Survey" questions elicit responses about the two basic components of ARL member budgets:

- The acquisitions or materials budget that is almost exclusively aimed at acquiring, in its many forms, scholarly information supporting the educational and research mission of universities. On average, in 2010-11 40.6\% of ARL budgets were expended on acquisitions. 
- In this article, as a shorthand the term "administrative budgets" has been applied to the sum of the remaining combined elements of budgeted funds-including personnel, operations, and all other categories, but excluding any capital-related funding. On average, in 2010-11 59.4\% of ARL budgets were expended collectively on these items.

\section{Fiscal Years Side by Side}

In FY11-12 76\% of ARL members (95 of 125) reported and in FY12-13 80\% (100 of 125) did so. The response rates were fairly stable for the two fiscal years across the four categories of membership-Canadian, US private universities, US public universities, and nonacademic (see Figure 1).

Figure 1. Budget Surveys FY2011-2012 and FY2012-2013: Responses by Member Type

\begin{tabular}{|r|cccc}
$\begin{array}{c}\text { FY2011-2012 } \\
\text { Member Type }\end{array}$ & Total Number & $\begin{array}{c}\text { Percentage of } \\
\text { Membership }\end{array}$ & Number of Responses & Percentage Responded \\
\hline Canadian & 16 & $13 \%$ & 10 & $63 \%$ \\
\hline US Private & 31 & $25 \%$ & 24 & $77 \%$ \\
\hline US Public & 68 & $54 \%$ & 55 & $61 \%$ \\
\hline Nonacademic & 10 & $8 \%$ & 6 & $76 \%$ \\
\hline Total & 125 & $100 \%$ & 95 & $70 \%$ \\
\hline
\end{tabular}

\begin{tabular}{|r|cccc}
\hline $\begin{array}{l}\text { FY2012-2013 } \\
\text { Member Type }\end{array}$ & Total Number & $\begin{array}{c}\text { Percentage of } \\
\text { Membership }\end{array}$ & Number of Responses & Percentage Responded \\
\hline Canadian & 16 & $13 \%$ & 13 & $81 \%$ \\
\hline US Private & 31 & $25 \%$ & 24 & $77 \%$ \\
\hline US Public & 68 & $54 \%$ & $58 \%$ \\
\hline Nonacademic & 10 & $8 \%$ & 100 & $50 \%$ \\
\hline Total & 125 & $100 \%$ & $50 \%$ \\
\hline
\end{tabular}

It is well established that academic libraries have historically faced outsized inflation rates for materials, that is rates frequently in excess of both the Consumer Price Index (CPI) and Higher Education Price Index (HEPI). ${ }^{5}$ This is particularly true for STM journal prices albeit less so for journals in other disciplines. From time to time, increases in scholarly monograph prices, notably from university and other nonprofit publishers, were in keeping with the indexes. All this is to say that the use of "inflation" here does not reflect the normal use of that economic term.

Note: The author wishes to give special thanks to Sarah Segura and Gregory Tucker for their assistance in preparing the tables and charts for this article. Their insights into how best to represent the data contributed measurably. 
The first question on the survey asks about the acquisition budget (see Figures 2 and 3).

Figure 2. Compared to the FY2010-2011 budget, the FY2011-2012 content acquisition budget:

\begin{tabular}{|c|c|c|c|c|c|c|c|}
\hline \multirow[b]{2}{*}{$\begin{array}{r}\text { Stayed the } \\
\text { same }\end{array}$} & & & & \multicolumn{2}{|c|}{ Total Responses $=95$} & \multirow{2}{*}{$\begin{array}{c}\begin{array}{c}\text { Response } \\
\text { Count }\end{array} \\
34\end{array}$} & \multirow{2}{*}{$\begin{array}{c}\begin{array}{c}\text { Response } \\
\text { Percent }\end{array} \\
36 \%\end{array}$} \\
\hline & $N=3$ & $N=5$ & $N=22$ & & $N=4$ & & \\
\hline $\begin{array}{r}\text { Increased } \\
1-3 \%\end{array}$ & $\mathrm{~N}=4$ & $N=6$ & $N=9$ & & & 19 & $20 \%$ \\
\hline $\begin{array}{r}\text { Increased } \\
4-6 \%\end{array}$ & $N=2$ & $N=10$ & $N=8$ & & & 20 & $21 \%$ \\
\hline $\begin{array}{r}\text { Increased } \\
7-9 \%\end{array}$ & $=1 \mathrm{~N}=2$ & $N=3$ & & & & 6 & $6 \%$ \\
\hline $\begin{array}{r}\text { Increased } \\
10 \% \text { or more }\end{array}$ & $N=1$ & & & & & 1 & $1 \%$ \\
\hline $\begin{array}{r}\text { Decreased } \\
1-3 \%\end{array}$ & $N=1$ & $\mathrm{~N}=1$ & & & & 9 & $10 \%$ \\
\hline $\begin{array}{r}\text { Decreased } \\
4-6 \%\end{array}$ & $N=3$ & & & & & 3 & $3 \%$ \\
\hline $\begin{array}{r}\text { Decreased } \\
7-9 \%\end{array}$ & $V=1$ & & & & & 1 & $1 \%$ \\
\hline $\begin{array}{l}\text { Decreased } \\
10 \% \text { or more }\end{array}$ & $N=1 N=1$ & & & & & 2 & $2 \%$ \\
\hline Can & adian & & US Private & US Public & & Non Acaden & \\
\hline
\end{tabular}

Figure 3. Compared to the FY2011-2012 budget, the FY2012-2013 content acquisition budget:

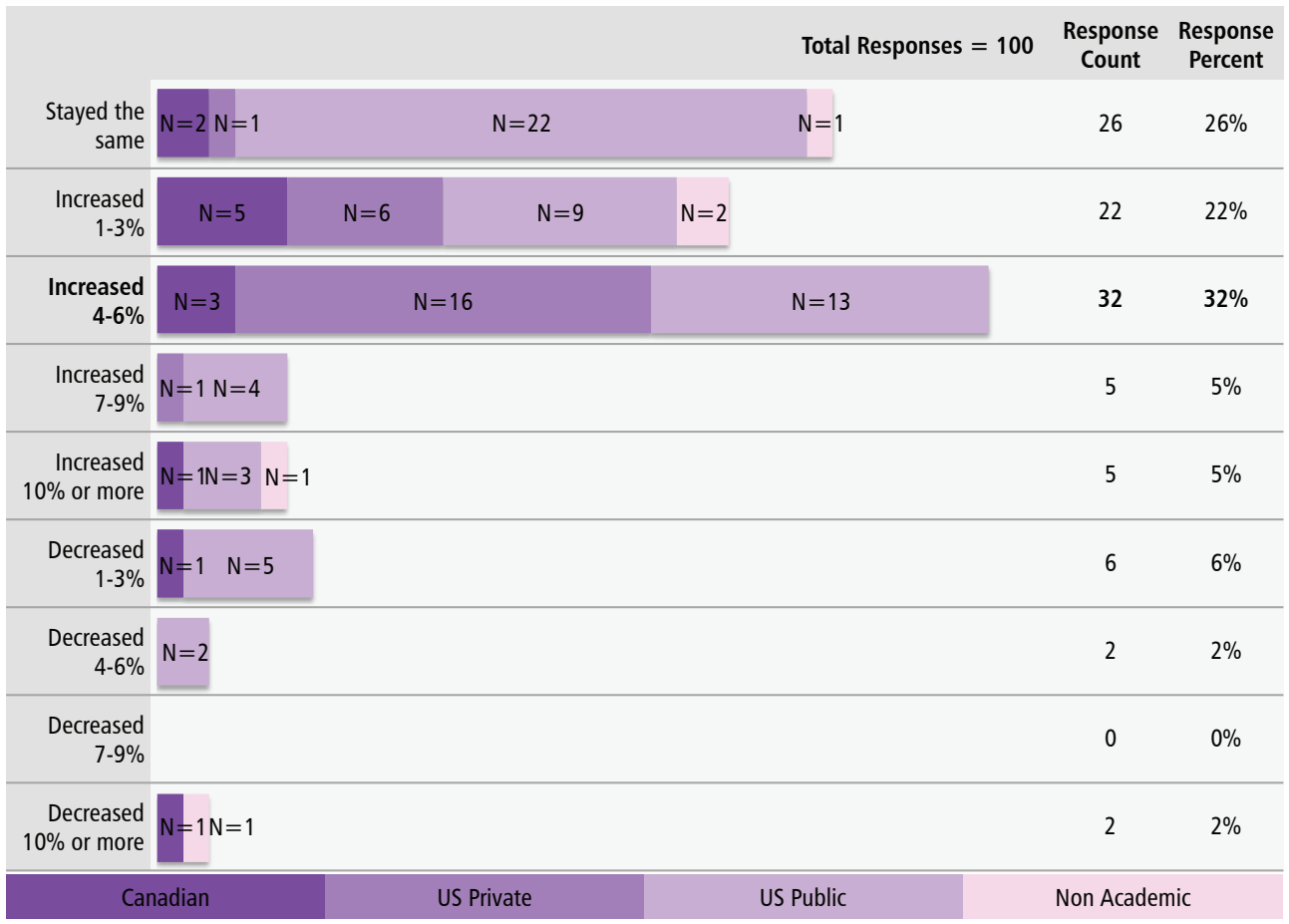


In FY11-12, four years after the initial fiscal 2008 collapse, 52\% of respondents reported flat or declining acquisition budgets. There were 19 libraries (20\%) that reported increases of 3\% or less, and that means that purchasing capacity was not keeping up with inflation. Taken together these figures mean that $72 \%$ of the ARL library acquisition budgets reflected a reduced access to information on campus. In FY1213 there is a trend toward some improvement. The number of member libraries unable to keep up with inflation had declined to 58\%. Or to put it positively, $42 \%$ received acquisition increases greater than 3\%, albeit some sectors of the industry increased prices faster still.

Turning to the topic of administrative budgets, it is important to note that the HEPI has over the longterm inflated faster than the CPI, effectively nullifying small increases in library administrative budgets that have personnel costs as their largest component. "HEPI is a more accurate indicator of changes in costs for colleges and universities than the more familiar Consumer Price Index. It measures the average relative level of prices in a fixed basket of goods and services purchased by colleges and universities each year through current fund educational and general expenditures, excluding research." ${ }^{\prime 6}$ During the period since 2008 while administrative budgets were being battered, HEPI continued increasing (see Figure 4). ${ }^{7}$

Figure 4. Comparison of HEPI and CPI 2008-2012

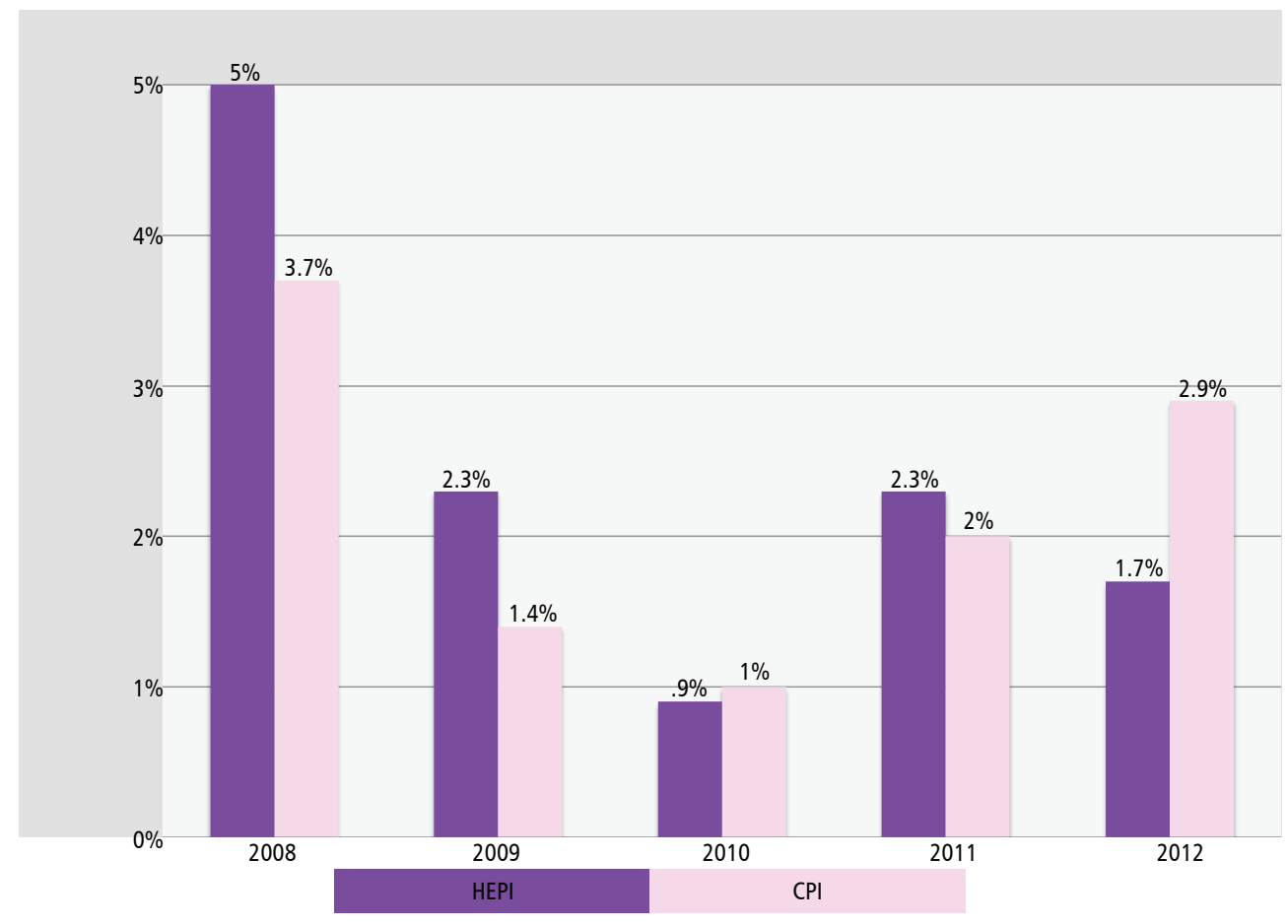


In FY11-12 89\% of reporting libraries had administrative budgets that did not keep up with inflation, that is increased less than 3\%, remained static, or were reduced from the previous year (see Figures 5 and 6).

Figure 5. Compared to the FY2010-2011 budget, the FY2011-2012 budget for all non-material items:

\begin{tabular}{|c|c|c|c|c|c|c|c|}
\hline \multirow[b]{2}{*}{$\begin{array}{l}\text { Stayed the } \\
\text { same }\end{array}$} & & & & & Total Responses $=95$ & \multirow{2}{*}{$\begin{array}{c}\text { Response } \\
\text { Count } \\
22\end{array}$} & \multirow{2}{*}{$\begin{array}{c}\begin{array}{r}\text { Respons } \\
\text { Percent }\end{array} \\
23 \%\end{array}$} \\
\hline & $N=4$ & $\mathrm{~N}=5$ & $N=11$ & $N=2$ & & & \\
\hline $\begin{array}{r}\text { Increased } \\
1-3 \%\end{array}$ & $N=3$ & \multicolumn{2}{|c|}{$\mathrm{N}=14$} & & $N=1$ & 33 & $35 \%$ \\
\hline $\begin{array}{r}\text { Increased } \\
4-6 \%\end{array}$ & $\mathrm{~V}=1 \mathrm{~N}=4$ & $\mathrm{~N}=4$ & & & & 9 & $10 \%$ \\
\hline $\begin{array}{r}\text { Increased } \\
7-9 \%\end{array}$ & $N=1$ & & & & & 1 & $1 \%$ \\
\hline $\begin{array}{r}\text { Increased } \\
10 \% \text { or more }\end{array}$ & & & & & & 0 & $0 \%$ \\
\hline $\begin{array}{r}\text { Decreased } \\
1-3 \%\end{array}$ & $V=2 N=1$ & & $\mathrm{~N}=17$ & $N=2$ & & 22 & $23 \%$ \\
\hline $\begin{array}{r}\text { Decreased } \\
4-6 \%\end{array}$ & $\mathrm{~N}=4$ & & & & & 4 & $4 \%$ \\
\hline $\begin{array}{r}\text { Decreased } \\
7-9 \%\end{array}$ & $\mathrm{~N}=1$ & & & & & 1 & $1 \%$ \\
\hline $\begin{array}{r}\text { Decreased } \\
10 \% \text { or more }\end{array}$ & $N=2 N=1$ & & & & & 3 & $3 \%$ \\
\hline & nadian & & US Private & & US Public & Non Academ & \\
\hline
\end{tabular}

Figure 6. Compared to the FY2011-2012 budget, the FY2012-2013 budget for all non-material items:

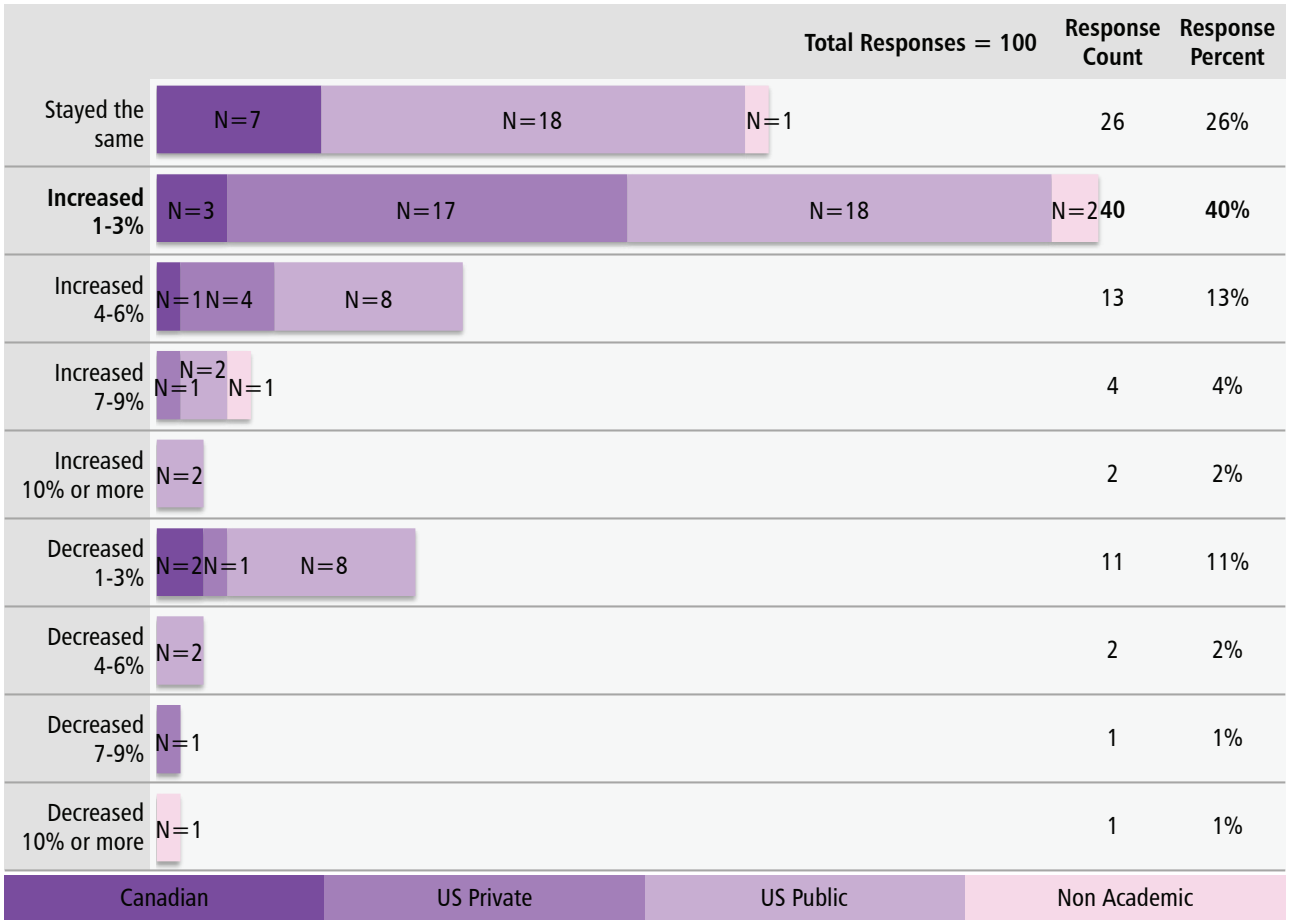


HEPI FY12-13 figures are not available as yet. All the same, the administrative budget numbers are worse than those for the acquisition portion of the budget and probably reflect some shifting of resources out of administrative budgets to assist in bolstering acquisitions. ARL members reported employing this strategy to preserve acquisitions during the previous three years. ${ }^{8}$ The FY12-13 numbers for administrative budgets showed little improvement with $81 \%$ of reporting libraries receiving budget allocations that did not keep up with inflation, that is increased less than $3 \%$, were static, or were reduced from the FY11-12.

The third question in the survey asks about increases in staff salaries (see Figures 7 and 8).

Figure 7. What, if any, salary increases were provided for your staff, excluding any promotion or retention related raises? (FY2011)

\begin{tabular}{|c|c|c|c|c|c|}
\hline & & & Total Responses $=95$ & $5 \begin{array}{c}\text { Response } \\
\text { Count }\end{array}$ & $\begin{array}{c}\text { Response } \\
\text { Percent }\end{array}$ \\
\hline $\begin{array}{r}\text { All eligible staff } \\
\text { received some } \\
\text { increase }\end{array}$ & $N=6$ & $N=22$ & $\mathrm{~N}=29$ & $N=3 \quad 60$ & $63 \%$ \\
\hline $\begin{array}{r}\text { Staff increases were } \\
\text { given to selective } \\
\text { categories }\end{array}$ & $N=4 N=1$ & $N=15$ & & 22 & $23 \%$ \\
\hline $\begin{array}{r}\text { No staff received } \\
\text { increases }\end{array}$ & $N=1 \quad N=11$ & $N=1$ & & 13 & $14 \%$ \\
\hline Canadiar & & US Private & US Public & Non Academ & \\
\hline
\end{tabular}

Figure 8. What, if any, salary increases were provided for your staff, excluding any promotion or retention related raises? (FY2012)

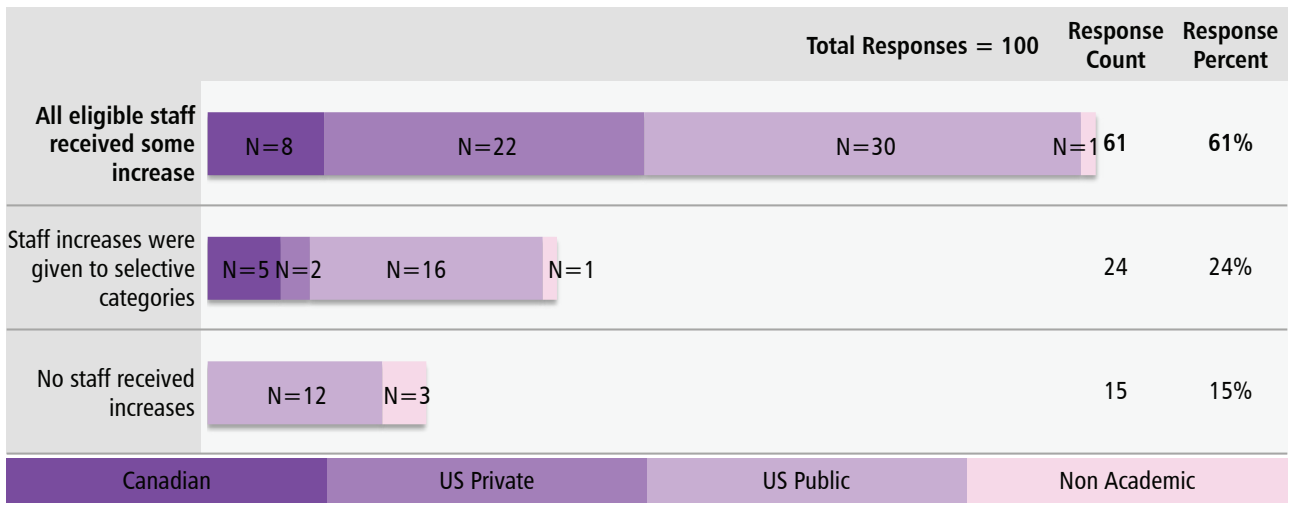

As can be seen, the results for both years were nearly identical with 61-63\% of members giving all eligible staff some increase and 23-24\% giving selective raises. A number of strategies were used to accomplish this seemingly counter-intuitive result. In the "Ten-Minute Survey" respondents were not asked specifically how funding was found to implement salary increases. However, in prior years the survey asked more detailed questions about how staff increases were managed. ${ }^{9}$ In order to garner savings in personnel budgets that could then be allocated to staff pay increases a number of strategies were noted: 
- Elimination of vacant positions

- Hiring freezes

- Staff layoffs

- Early-retirement program

- Staff furloughs

- Unspent funds from prior year

One can presume that some of these strategies have been at play in recent fiscal years as well. The written commentary indicates increases were frequently the result of union contracts or were targeted retentions for high-performers. One should keep in mind too that ARL libraries have for some years been finding ways to reduce staff numbers through numerous efficiency and service-improvement strategies and this trend has accelerated in the last five years. This means that the same salary pool can be spread across smaller numbers of staff thus allowing for increases even in difficult times. In any event, the fact that member institutions were awarding increases is a positive reversal of the multi-year trend since 2008 and indicative of the commitment to retaining talented and valuable staff. Moreover, written comments indicate that awards were not stingy, particularly given the cost-of-living changes indicated by the CPI (see Figure 9). When amounts were provided, in FY11-12 nearly two-thirds of the awards were $2.9 \%$ or less. On the other hand, the remaining one-third was 3\% or more. In FY12-13 slightly over half were 2.9\% or less, so almost half were $3 \%$ or more.

Figure 9. Provide details regarding increments of increase:

\begin{tabular}{|c|c|c|c|c|c|c|}
\hline FY2011-2012 & & & & Total Responses $=26$ & $\begin{array}{c}\text { Response } \\
\text { Count }\end{array}$ & $\begin{array}{c}\text { Response } \\
\text { Percent }\end{array}$ \\
\hline Range $1-2 \%$ & $N=4$ & $N=5$ & $N=1$ & & 10 & $38 \%$ \\
\hline Range $>2-2.9 \%$ & $\mathrm{~N}=3$ & $\mathrm{~N}=4$ & & & 7 & $27 \%$ \\
\hline Range $3 \%$ or more & $\mathrm{N}=5$ & $\mathrm{~N}=4$ & & & 9 & $35 \%$ \\
\hline
\end{tabular}

\begin{tabular}{|c|c|c|c|c|c|c|}
\hline FY2012-2013 & & & & Total Responses $=39$ & $\begin{array}{l}\text { Response } \\
\text { Count }\end{array}$ & $\begin{array}{c}\text { Response } \\
\text { Percent }\end{array}$ \\
\hline Range $1-2 \%$ & $\mathrm{~N}=3$ & $N=1 \quad N=2 \quad N=1$ & & & 7 & $18 \%$ \\
\hline Range $>2-2.9 \%$ & & $N=7$ & $N=7$ & & 14 & $36 \%$ \\
\hline Range $3 \%$ or more & $=1$ & $N=8$ & $\mathrm{~N}=9$ & & 18 & $46 \%$ \\
\hline
\end{tabular}

Note: 39 of the 61 libraries that gave increases to all eligible staff provided details concerning the amounts given.

$\begin{array}{llll}\text { Canadian } & \text { US Private US Public Non Academic }\end{array}$




\section{Discerning Patterns from the 88 Libraries}

As mentioned in the introduction, 88 libraries (70\% of ARL members) answered the survey for both fiscal years-9 Canadian, 23 US private universities, 52 US public universities, and 4 nonacademic. This allows for a cross tabulation of the two years, enriching understanding and allowing some speculation about trends. Scatterplot bubble charts are used here to illustrate the patterns from one fiscal year to the next because these reflect magnitude and graphically demonstrate the clustering/distribution of activity.

The acquisition budgets of these 88 libraries show that 41 (46.5\%) experienced increases (upper half of chart), however small, in FY11-12 (see Figure 10). However, the data show (upper right quadrant) that only $30(34 \%)$ received some increase again in FY12-13. This slightly positive news is attenuated by the fact that 14 libraries (16\%) increased 3\% or less both years, thus losing ground against inflation. Eleven of the 88 libraries (13\%) received increases in FY11-12 but had flat budgets or budget cuts in FY12-13 (upper left quadrant). To put a fine point on it, of the 41 libraries that received some increase in FY11-12, 25 (61\%) lost ground against inflation in FY12-13. Of the 47 libraries that experienced flat or reduced acquisition budgets in FY11-12, only 4 (9\%) received FY12-13 increases greater than inflation (4\% or greater). In summary, both years in succession 68 of the 88 libraries (over 77\%) were assigned budgets that grew less than inflation, stayed flat, or declined. This does not look like a trend that will soon restore the pre-2008 buying power of acquisition budgets of ARL members. 
Figure 10. Acquisitions Budgets, FY2011-2012 \& FY2012-2013

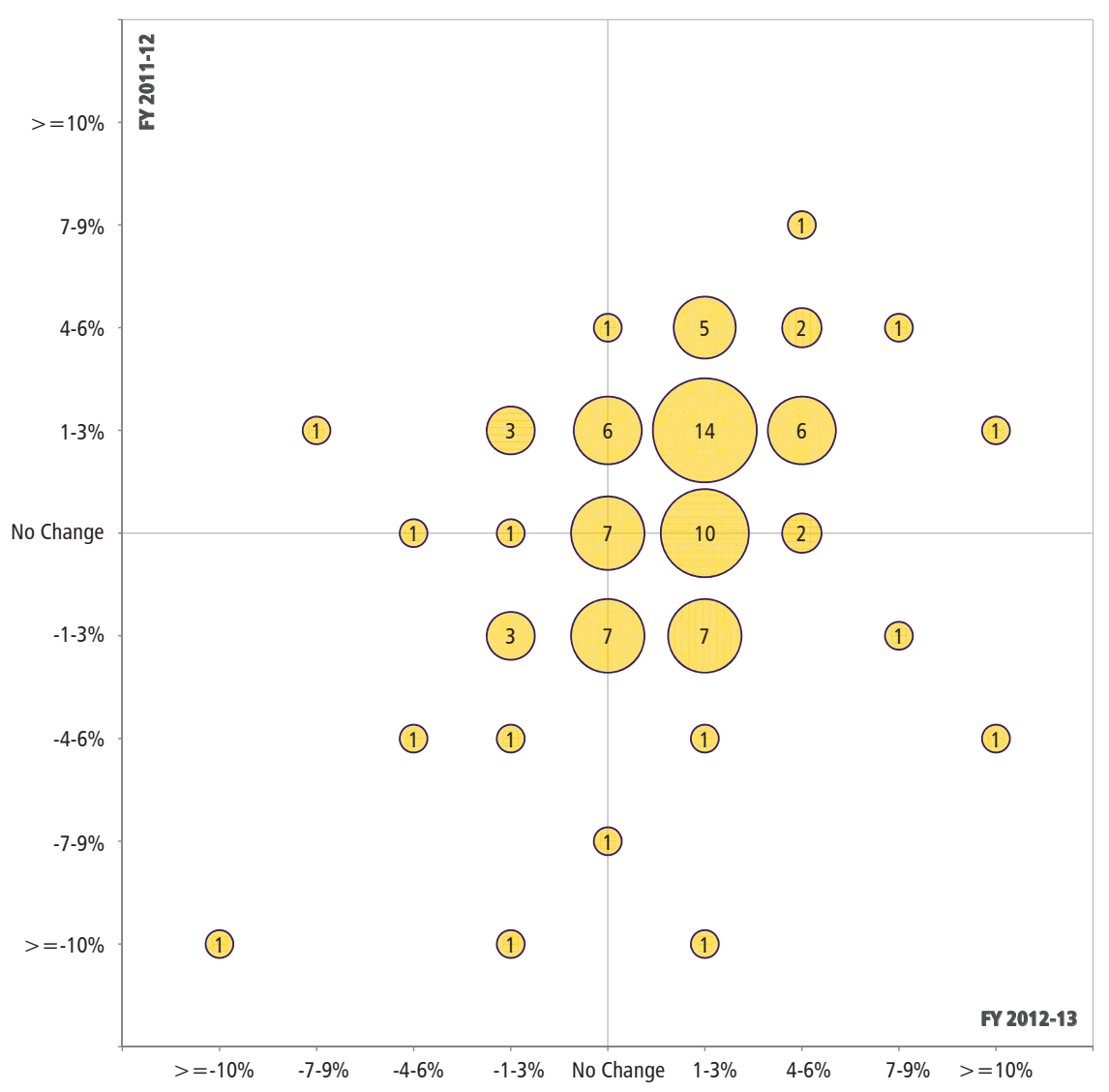

These patterns were distributed unevenly across the categories of membership. For instance, among ARL US public university members a mere 15 of the 52 (29\% of the cohort) received increases both years. By contrast 15 of 23 US private university members (65\% of the cohort) experienced increased acquisition budgets each of two successive fiscal years. A 2010 internal ARL survey indicated that $3 \%$ of the budgets for public institutions were dependent on endowments while the figure was close to $14 \%$ for private ARLs. Endowments are singularly focused on acquisitions and it is clear that the rebound in endowments has been a real benefit to these members of the Association. Canadian members of ARL seemed immune in the early years of the downturn. However, fewer than half of those reporting experienced increases in the two most recent fiscal years.

The administrative budgets of these same 88 libraries reflect a pattern that is similar to that of the acquisition budgets. Keep in mind that the largest component of administrative budgets is personnel salaries, where institutions were making a commitment to staff, some for the first time in three years. Figure 11 illustrates the point. The data show (upper right quadrant) that 36 libraries $(41 \%)$ received increases in both fiscal years, but 7 of these were $3 \%$ or less and did not mark a significant improvement against the HEPI. Notably, 25 libraries (28\%) lost ground-receiving flat or reduced budgets both fiscal years. The remaining 27 responding libraries $(31 \%)$ had an uneven experience, receiving either flat or reduced administrative budgets one year and increases in the other. 
Figure 11. Administrative Budgets, FY2011-2012 \& FY2012-2013

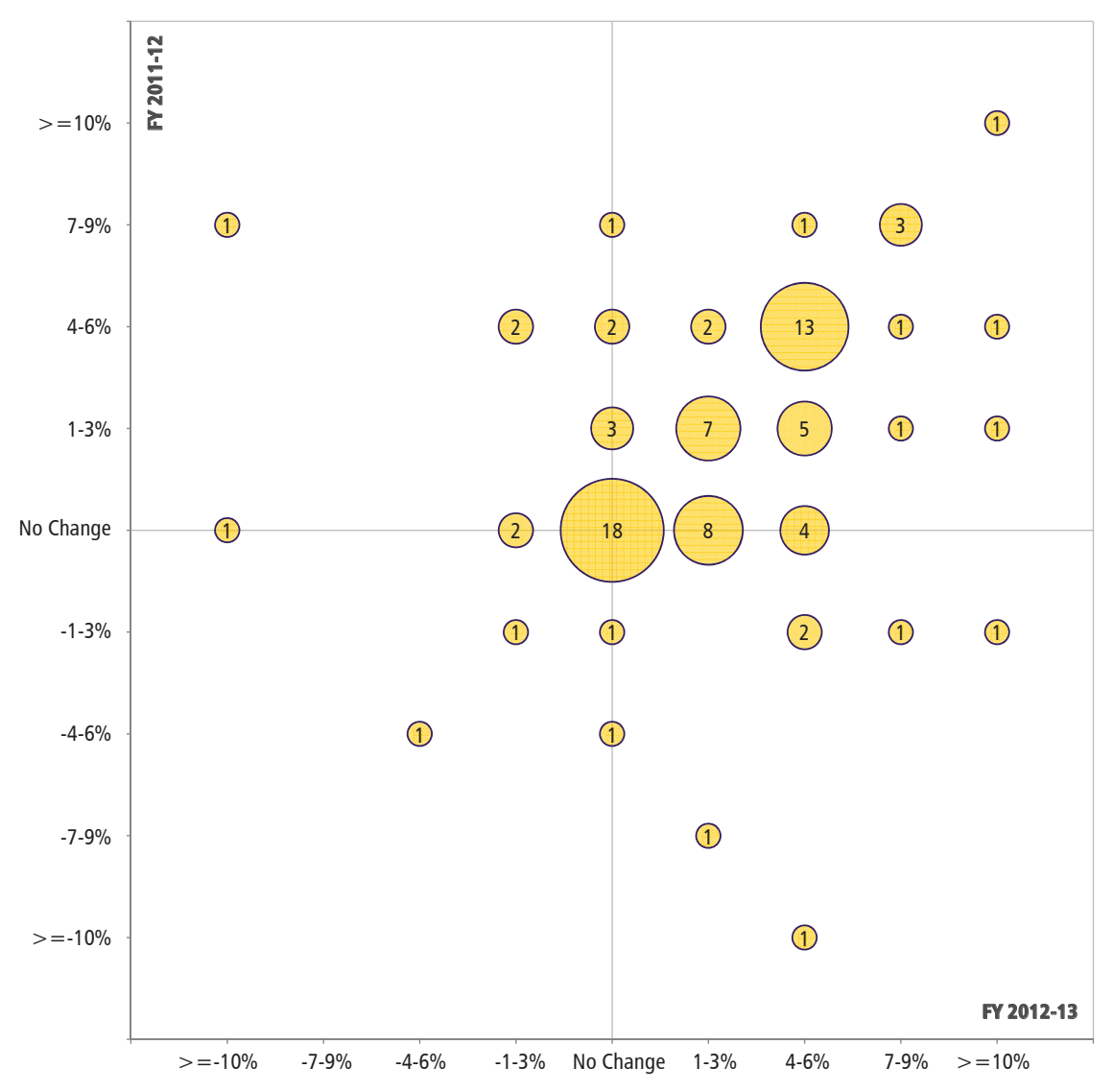

\section{Conclusions}

The question one should ask is whether the data ARL has collected since 2008 begins to reveal a trend that might inform the future. Even the modest improvements of the last two years represent less positive news when viewed over the arc of acquisition budgets that have been static or trending downward since 2008. To put it another way-after three years of serious retrenchment an increase of 3\% or less is hardly sufficient to restore the pre-2008 purchasing power of acquisition budgets. Nor is it heartening that such a large number of member libraries, after five years, still face flat budgets or continued serious retrenchment. The picture is no better for administrative budgets in member libraries.

For many, the pattern of increases one year combined with decreases or flat budgets another means that we continue in a very volatile period for research library funding. This has not been the historic pattern for ARL institutions. Albeit the decades-long trend has meant budgets frequently have not kept up with inflation, no period has witnessed the absolute declines in the dollars being allocated to these budgets. In short, for five years ARL institutions have been in a pattern that departs from the historic expectation of increased funding intended to at least ameliorate the inflation rate for library acquisitions and the cost of operations and personnel. Like acquisitions, administrative budgets have demonstrably suffered more since 2008 than at any time in recent decades. In sum, the downturn of 2008 was followed by a progressive de-funding of library budgets that reflected what was happening in higher education 
institutions generally. Recent years are best characterized as highly volatile. The trends do not encourage optimism that budgets have turned the corner, and this will have consequences for the teaching and research within higher education and in the market place of scholarly communications internationally.

\section{Endnotes}

1 ARL Statistics (Washington, DC: Association of Research Libraries, annual).

2 "ARL FY 2012-2013 Budget Survey" is an example of the stable instrument, see https://www. surveymonkey.com/s/JQ3G8NT.

3 National Association of State Budget Officers, The Fiscal Survey of States, Fall 2012 (Washington, DC: National Association of State Budget Officers, 2012), ix, vii, http://www.nasbo.org/sites/default/ files/Fall 2012 Fiscal Survey.pdf.

4 Charles B. Lowry, "Year 2 of the 'Great Recession': Surviving the Present by Building the Future," Journal of Library Administration, Haworth Press, 51, no. 1 (January 2011): 37-53; Charles B. Lowry, "Three Years and Counting-The Economic Crisis is Still With Us," portal: Libraries and the Academy, 11, no. 3 (2011): 757-64.

5 See, for instance, Dave Bogart, ed., Library and Book Trade Almanac, 56th ed. (Medford, NJ: Information Today, Inc., 2011), 461-90.

6 "About HEPI," Commonfund, accessed March 6, 2013, http://www.commonfund.org/ CommonfundInstitute/HEPI/Pages/default.aspx.

7 “2012 HEPI Update” Commonfund, accessed May 3, 2013, http://www.commonfund.org/ CommonfundInstitute/HEPI/HEPI Documents/CF_HEPI_2012.pdf.

8 Lowry, “Year 2 of the 'Great Recession,'” 761-62.

9 Ibid, 95.

(C) 2013 Charles B. Lowry

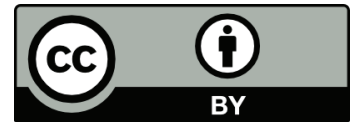

This article is licensed under a Creative Commons Attribution 3.0 Unported License. To view a copy of this license, visit http://creativecommons.org/licenses/by/3.0/.

To cite this report: Charles B. Lowry. "ARL Library Budgets after the Great Recession, 2011-13." Research Library Issues: A Report from ARL, CNI, and SPARC, no. 282 (2013). http://publications.arl.org/ rli282/. 


\title{
The State of Large-Publisher Bundles in 2012
}

\author{
Karla L. Strieb, ${ }^{1}$ Associate Director, Collections, Technical Services and Scholarly Communication, Ohio \\ State University Libraries \\ Julia C. Blixrud, Assistant Executive Director, Scholarly Communication, Association of Research \\ Libraries
}

\section{A Decade of Experience with Journal Bundles}

or well over a decade, research libraries have been spending millions of dollars per year licensing collections of journals published by just a handful of publishers. Ten years ago ARL surveyed its membership about their licensed collections of journal titles. In 2002, ARL asked for information regarding members' expenditures for 60 journal publishers, ultimately reporting findings for the 7 most commonly subscribed publishers. In 2003, a second survey added further information about some licensing terms. ${ }^{2}$ ARL surveyed its members again in 2005 about their 2006 licenses with the 6 largest publishers at that time. ${ }^{3}$ Early in the summer of 2012, ARL again surveyed its member libraries about their subscriptions to journal collections from large publishers. ${ }^{4}$ The data collected in this most recent survey show that a great deal has changed in the last decade, and yet several issues remain concerns within the library community. Pricing models and license terms, consortial arrangements, and the conversion from print to electronic subscriptions remain issues across the surveys.

Interest in research library subscriptions to large-publisher bundles persists for several reasons. Perhaps the primary reason is that, for more than a decade, a small group of publishers account for a disproportionate amount of libraries' materials expenditures. Although it is difficult or perhaps impossible to gather accurate, comparable data on the prices libraries are paying for the largest publishers' journals, there is no question that these are the most expensive purchases research libraries are making with their materials dollars. How libraries can manage these expenditures, and how much value they receive for them, is mediated by the terms of the licenses that define these cornerstone purchases. License terms have been an issue of discussion within the research library community since the beginning of e-journal production. Initially, identifying key issues for negotiation was a primary focus. More recently, concern about the frequency and effect of nondisclosure clauses has generated community debate. New discussion threads have arisen around license terms that may be of particular interest to research libraries, such as text-mining rights, the ability to archive articles by authors affiliated with the licensee, details of ILL requirements, and preservation-related terms.

Another much-discussed element in the landscape of large-publisher licenses has been the ability to cancel titles within collections or otherwise manage inflation or reduce expenditures as needed by subscribing libraries. A major, global recession began in 2008, and surveys of ARL members throughout the recession documented considerable financial strains on member library budgets. ${ }^{5}$ The goal of this article reporting results of the 2012 survey is to help the community understand how well libraries were able to manage expenditures in the face of their long-term, high-cost commitments to large publishers, and what changes in licensing terms and practices occurred. 


\section{Signs of Change}

Comparing surveys from 2002, 2005, and 2012 shows the steady uptake of the largest publisher bundles. Three of the four publishers covered in the two most recent surveys (Elsevier, Springer, and Wiley) are now licensed as bundles by $90 \%$ or more of libraries for which data were collected (see Table 1). Even for Taylor \& Francis, which was the least frequently licensed bundle in both surveys, market penetration tripled. Although several libraries have discussed dropping bundles, it appears within this market segment that, overall, subscription has grown over the last six years. Some libraries may have dropped bundles but, if so, their actions were more than counterbalanced by libraries taking on licenses for journal bundles. For 2012, the average responding libraries had licensed more than five bundles among the seven publishers.

Table 1. Research Library Uptake of Journal Bundles

\begin{tabular}{|l|c|c|}
\hline Publisher & \% Licensed in 2012 & \% Licensed in 2006* \\
\hline American Chemical Society & $97 \%$ & N/A \\
Elsevier & $92 \%$ & $80 \%$ \\
Nature & $86 \%$ & N/A \\
Sage & $89 \%$ & N/A \\
Springer & $95 \%$ & $77 \%$ \\
Taylor \& Francis & $57 \%$ & $19 \%$ \\
Wiley & $96 \%$ & $81 \%$ \\
\hline
\end{tabular}

* Data based on combination of responses to ARL 2005 survey of "have licensed [for 2006]" and "planning to license [for 2006]."

However, the definition of the subscription bundle has changed for many libraries since the 2006 subscription year. There is evidence of substantial pruning of journal bundles through the "Great Recession." Six years ago, many more libraries described their bundles as including all of a publisher's titles. For the four publishers covered in both studies, percentages of libraries reporting the full publisher list of titles dropped noticeably for all (see Table 2). The data are consonant with a shift in consortial licensing from packages of publishers' full lists to pooled lists of titles licensed by consortia members. However, for those publishers in both surveys, substantially more libraries are now defining their bundle at the institutional level. In 2006, fewer than $10 \%$ of subscribing libraries defined their own bundles with Wiley, Springer, and Taylor \& Francis (rather than as a consortial pool or the full list). By 2012, the percentage of libraries with institutionally defined bundles tripled for Wiley and Taylor \& Francis licensors, while the proportion institutionally defining the Elsevier bundle more than doubled. Even the proportion of institutionally defined Springer licensors increased somewhat. 
Table 2. Research Library Definition of Journal Bundles

\begin{tabular}{|l|c|c|}
\hline Publisher & \% Licensed All Titles in 2012 & \% Licensed All Titles in 2006* \\
\hline Elsevier & $23 \%$ & $32 \%$ \\
Springer & $36 \%$ & $50 \%$ \\
Taylor \& Francis & $26 \%$ & $87 \%$ \\
Wiley & $19 \%$ & $37 \%$ \\
\hline
\end{tabular}

* Data based on combination of responses to ARL 2005 survey of "have licensed [for 2006]" and "planning to license [for 2006]."

Regardless of recent changes, the role of consortia continues to be pivotal for the largest publisher bundles. As the overall percentages of libraries licensing with the biggest publishers have gone up, the proportion of licenses that are managed through consortia remains remarkably similar for 2006 and 2012 subscriptions, with one exception (see Table 3). Over the last six years Taylor \& Francis has been making up for a later migration to electronic publishing and consortial licensing is clearly part of the reason.

Table 3. \% of Contracts Licensed via Consortium

\begin{tabular}{|l|r|r|r|}
\hline Publisher & $\mathbf{2 0 1 2}$ & $\mathbf{2 0 0 6}$ & $\mathbf{2 0 0 3}$ \\
\hline American Chemical Society & $71 \%$ & N/A & $46 \%$ \\
Elsevier & $61 \%$ & $63 \%$ & $39 \%$ \\
Nature & $84 \%$ & N/A & N/A \\
Sage & $91 \%$ & N/A & N/A \\
Springer & $97 \%$ & $95 \%$ & $37 \%$ \\
Taylor \& Francis & $68 \%$ & $20 \%$ & $3 \%$ \\
Wiley & $96 \%$ & $94 \%$ & $53 \%$ \\
\hline
\end{tabular}

Over the last decade, ARL's member surveys have documented a remarkable shift in the move of research libraries away from collecting current journals in print form. Already in 2003, Case was observing a rapid shift from bundled print and electronic subscriptions to electronic-only subscriptions. ${ }^{6}$ By 2006 , print equivalents had been cancelled for 153 out of 266 contracts $(58 \%)$ for the five publishers covered by that survey. In 2012, with the exception of a single publisher (Taylor \& Francis), no libraries reported that they retained corresponding print subscriptions for their complete journal bundles (7 out of 352 contracts still included print, or 2\%). However, $23 \%$ to $43 \%$ of respondents (by publisher) indicated that they still carried some selected print titles in 2012. This suggests that there are some instances where publishers have not yet fully implemented digital publishing or developed fully substitutable digital versions for some journals; or, perhaps some users are not yet ready to support cancellation for individual titles. 
The ability to cancel titles (or not) has been a concern about journal bundles from the beginning. The most recent survey reinforces the findings from the earlier ARL surveys that only a small minority of libraries retain any ability to cancel titles within their bundle during the term of their license (for those able to disclose, $39 \%$ of contracts forbid any cancellations under any circumstances during the length of the contract, and another $24 \%$ cannot do so without declaring a fiscal emergency). However, the reduction in full-list bundles reported suggests that, between 2006 and 2012, many libraries have reduced the extent of their bundles between contracts. Given the budget reductions reported in ARL's surveys on library budgets conducted in 2009, 2010, and 2011, following the onset of the most recent recession, ${ }^{7}$ one might anticipate that libraries would press for more liberal cancellation options. However, there is no evidence within the survey data to support this hypothesis.

\section{How Long Can Historic Pricing Last?}

To an outside observer it might be surprising to see that more than a decade into electronic journal licensing, historic subscription expenditure remains by far the dominant model for determining library pricing. For most of the 375 contracts for which pricing model was reported, libraries' prices are determined by their historic print subscriptions (now dating back to the 1990s in many cases), plus inflation increments applied annually during the intervening years. For the four largest publishers, $82 \%$ of contracts are priced in this way. This could be seen as even odder given that the survey also provides evidence of many institutions' having reduced the content in their bundles from the publisher's full list to some subset defined for a consortium or at the institutional level. Two publishers appear to have largely shifted their pricing models to either a form of tiered pricing (larger institutions pay more than smaller institutions) or simply an aggregate subscription price for all of the titles in the bundle. In contrast to the four largest publishers, the American Chemical Society and Nature differ not just in their abandonment of historical pricing strategies but as publishers with small title lists and control of top-tier journals in their field. While usage-based pricing has generated some discussion as a potential alternative pricing model for large-publisher collections, it does not appear to have found expression in any significant way within the research library community.

\section{Licensing Terms and Clauses}

The research library community shares an interest in most journal contract terms and clauses with other types of libraries. There are additional terms that are also of particular interest, because of the nature of a research library clientele. The 2012 survey included questions about some specific terms and clauses now being included in licensing agreements in order to understand the current licensing environment.

The ability to share information about contract terms, as well as pricing information-and thus allow the research library community to collectively advance its positions regarding access to content-is dependent on the knowledge of what is in the agreements. In May 2009, the ARL Board of Directors, based upon the recommendation of the Advancing Scholarly Communication Steering Committee, issued a statement encouraging members to refrain from signing nondisclosure clauses in their licenses. The 2012 survey asked two questions regarding nondisclosure. The first was whether members had policies to refrain from signing nondisclosure clauses. Of the 50 respondents, just under half (49\%) indicated 
that they had such a policy now. Respondents' comments provided some useful perspective: for many institutions, even if the signed license states that nondisclosure is required, the institution abides by the law of their state, and respondents presumed that open records acts apply.

Recent attention surrounding nondisclosure clauses has, however, resulted in an increasing number of institutions that are now in the process of establishing a policy not to sign such clauses. An interesting comparison can be made to data collected for the 2003 survey. In that survey, ARL asked about the legality of licenses with nondisclosure clauses. Twenty-six public institutions reported that they were legal in their jurisdictions, and 20 (77\%) of those 26 institutions did accept those clauses, although some reported that they were subject to sunshine laws and FOIA requests. ${ }^{8} \mathrm{~A}$ similar percentage of 11 private institution responses was reported. It is encouraging that over this ten-year period, more institutions are attempting to refrain from signing nondisclosure clauses.

The second question in the recent survey asked whether nondisclosure clauses were signed for the 2012 contract for specific publishers (Table 4). Depending on the publisher, a range of 10-28\% of respondents indicated that they had indeed signed a nondisclosure clause. When comparing the data with that of 2006, it appears that significant progress was made with Wiley and Taylor \& Francis, since the percent of nondisclosure dropped by two-thirds and by more than half, respectively. Elsevier decreased slightly, but Springer, however, rose $11 \%$, raising questions as to whether it increased the pressure on libraries to sign nondisclosure after the open-records decision in the state of Washington in 2009. ${ }^{9}$ Again, the comments for 2012 indicated that some libraries assumed open records laws applied to contract terms.

The role of consortia cannot be overstated here, since they negotiate many large bundles on behalf of the libraries. Those consortia that have recently or are now establishing nondisclosure policies will affect the responses to this question in the future.

Table 4. Libraries that Reported Signing Nondisclosure Clauses

\begin{tabular}{|l|c|c|c|c|}
\hline Publisher & 2012 Contracts & \% Nondisclosure & 2006 Contracts & \% Nondisclosure \\
\hline ACS & 48 & $10 \%$ & N/A & N/A \\
Elsevier & 47 & $25 \%$ & 50 & $28 \%$ \\
Nature & 42 & $19 \%$ & N/A & N/A \\
Sage & 43 & $21 \%$ & N/A & N/A \\
Springer & 46 & $28 \%$ & 36 & $17 \%$ \\
Taylor \& Francis & 34 & $9 \%$ & 10 & $20 \%$ \\
Wiley & 48 & $21 \%$ & 61 & $61 \%$ \\
\hline
\end{tabular}

ARL also is supporting model author-rights clauses that provide for open access deposit of works by the institution's authors. Only a very small number of libraries did attempt to negotiate this clause for 2012 contracts, but of those libraries there are success stories of at least $50 \%$ or more for nearly all of the publishers. This should encourage other research libraries to consider adding this clause to their license, and respondent comments indicated that some were expecting to do so in the future. 
The ability to text mine is a very new license consideration, and libraries were asked if they were beginning to negotiate that clause. No conclusions could be drawn from the low response to this question, but comments indicated that many research libraries are beginning to work with the journal publishers to address this need.

In addition to nondisclosure and author-rights clauses, interlibrary loan terms in licenses—which vary among the large-publisher bundles-are also of particular interest to ARL. The 2012 survey asked libraries to identify any clauses that address fulfillment of ILL requests. The responses included information on publishers that allow sending printed articles (58\% to 79\%), allow the transmission of electronic articles (39\% to 73\%), and allow international interlibrary loan (11\% to 36\%). A small number of libraries indicated that the contract was silent on ILL. The variation in response, and a review of the comments, indicate a lack of consistency among publishers and even among libraries that may have signed agreements with the same publisher. The challenge for future contracts is to make sure that any licenses being signed do not abridge a library's ability to share materials.

Two other questions about general license terms dealt with preservation, and the responses indicated that for each publisher slightly more than half of the 2012 contracts addressed preservation of licensed content either locally or through third parties, though the specifics of how that will be done were not requested in the survey. More specific surveys will need to be done to determine how the large packages are being preserved and the license clause language used to ensure that long-term preservation needs are being met.

The final question about specific terms asked whether access could be retained for content that was subscribed to in the past. High percentages were reported for each publisher ( $76 \%$ to $90 \%$ ), but comments indicated that some publishers require a fee. License terms that provide research libraries with the ability to provide access to content they have previously licensed is a potential area in which to advance new and more detailed terms.

\section{What Is Next?}

The information about ARL member libraries collected for this study demonstrates ongoing strains in libraries' relationships with publishers and in their ability to maintain electronic journal bundles in difficult financial times. A great divide is evident between the anticipated promise of electronic publishing foreseen at the birth of journal bundles and the reality of large-publisher journal licensing in 2012. Fully digital collections of big publishers' journals are the norm in research libraries, and license negotiations are beginning to address issues such as text-mining rights, harbingers of the potential benefit of a fully digital scholarly communication system.

Yet, the expected opportunity to make more content available to libraries than could be afforded through print subscriptions seems to have largely evaporated. Research libraries are more frequently subscribing to subsets of publishers' lists than they were six years ago, while still paying for their access largely based on print subscription costs grounded in an increasingly distant past. Content and pricing seem to be 
trending toward a growing disconnect. Consortial licensing offers continuing benefits to institutions, but less and less often that benefit seems to be including access to a larger body of content.

The licenses that are signed by the libraries or the consortia that represent them need stronger language in the clauses that are important to the research library community. The ability to use the content in new ways, the importance of sharing information between and among researchers and institutions, and the expectation that content will be available in the future all require diligent examination of and development of clauses that meet those needs. Especially important will be the emphasis on moving away from nondisclosure clauses to better position research libraries to negotiate license terms and prices individually or with their consortia more effectively.

The authors acknowledge the value of the time taken by respondents to answer the survey and thank them for their willingness to share information about their contracts.

\section{Endnotes}

1 The author published formerly under the name Karla Hahn and conducted an earlier journalbundle study for ARL cited in this report.

2 Mary M. Case, "A Snapshot in Time: ARL Libraries and Electronic Journal Resources," ARL: A Bimonthly Report on Research Library Issues E Actions, no. 235 (Aug. 2004): 1-10, http://www.arl.org/ storage/documents/publications/arl-br-235.pdf.

3 Karla L. Hahn, "The State of the Large Publisher Bundle: Findings from an ARL Member Survey," ARL: A Bimonthly Report on Research Library Issues \& Actions, no. 245 (Apr. 2006): 1-6, http://www.arl. org/storage/documents/publications/arl-br-245.pdf.

4 In the 2012 survey, 81 ARL member libraries responded, describing licenses and providing related information.

5 Charles B. Lowry, "Year 2 of the 'Great Recession': Surviving the Present by Building the Future," Journal of Library Administration 51, no. 1 (2010): 37-53; and see Karla L. Hahn, "ARL Statement to Scholarly Publishers on the Global Economic Crisis," Research Library Issues: A Bimonthly Report from ARL, CNI, and SPARC, no. 262 (Feb. 2009): 6-11, http://publications.arl.org/rli262/7.

6 Mary M. Case, "A Snapshot in Time."

7 Charles B. Lowry, "Year 2 of the 'Great Recession.'”

8 Mary M. Case, "A Snapshot in Time."

9 "Elsevier Motion to Block License Release Denied in Open-Records Decision," ARL news item, June 23, 2009, http://www.arl.org/news/arl-news/2421-elsevier-motion-to-block-license-release-denied. 
(C) 2013 Karla L. Strieb and Julia C. Blixrud

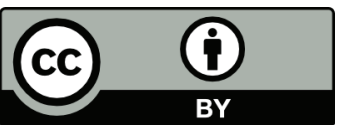

This article is licensed under a Creative Commons Attribution 3.0 Unported License. To view a copy of this license, visit http://creativecommons.org/licenses/by/3.0/.

To cite this report: Karla L. Strieb and Julia C. Blixrud. “The State of Large-Publisher Bundles in 2012." Research Library Issues: A Report from ARL, CNI, and SPARC, no. 282 (2013). http://publications.arl.org/ rli282/. 


\title{
Evolving Models of Reference Staffing at the University of Kansas Libraries
}

\section{Frances Devlin, University of Kansas \\ John Stratton, University of Kansas}

\begin{abstract}
he proliferation of digital resources and technologies, coupled with a general decline in reference questions asked in research libraries, have brought new dimensions to librarianship and traditional reference services at ARL libraries. At the University of Kansas (KU) Libraries, reference services have evolved and been reconfigured several times over the past decade. Modifications to the service model have been made in response to changing user behaviors and technologically enhanced access to scholarly resources, and to focus on better utilization of library faculty time. In recent years, for example, librarians have assumed greater responsibilities while facing increased demands on their time, with expanded leadership roles in areas such as open access publishing, copyright consultancy, data services management, and classroom teaching. Given these changes in emphases, KU Libraries' reference services have evolved to include formerly non-reference staff (i.e., paraprofessionals) who did not normally work in public service areas, but who nonetheless expressed a desire to work at the desk as a way to enhance their own skills. Over time, this staffing model has proven successful and, through a series of changes to the overall reference model, has been retained as an innovative and effective way to expand reference services and tap into expertise offered by library paraprofessionals.
\end{abstract}

\section{Early Changes}

Prior to 2002, KU Libraries had a traditional reference staffing model in Watson and Anschutz Libraries, which together contain the bulk of the collections for the humanities, social sciences, and sciences. Each library had its own reference desk and department, staffed by subject librarians housed in those locations. Due to anticipated budget cuts in 2002, the library administration implemented a pilot project integrating the functional units of reference and access services across the Anschutz and Watson Libraries. Following the departure of the head of Anschutz Library in 2002, it was decided that the position would not be filled. Instead, the library administration merged these separate reference departments, and the new combined unit was led by two co-coordinators. While it took some time for librarians and departmental staff to become used to the new arrangement and to working at both reference desks, eventually all made the transition. It was also during this same period that chat and instant messaging modes of communication were introduced as part of reference services, staffed separately away from the desks by librarians.

In 2004, within two years of the merged approach, the library administration introduced another new reference staffing model, which was christened the "peer and tier" model and was based on the Brandeis Reference Model. This new model's central feature was to place students and paraprofessionals at the Watson and Anschutz reference desks, backed up by librarians in their offices. Librarians, it was presumed, would concentrate on other duties, including outreach to academic departments, basic and 
advanced instruction, and staff training for desk services. In addition, librarians would be "on call" to assist desk staff with complex research questions. It should be noted that most of the students hired to work in the peer and tier structure were undergraduates, not graduate students.

At this juncture, since librarians were working fewer hours at the reference desks, overtures were made to paraprofessional staff from other areas of the libraries-interlibrary loan, cataloging, and other library branches-to consider volunteering to perform reference desk service to augment other reference paraprofessional staff still performing this work. Many staff responded to that call and their presence helped maintain the reference desk schedule to meet user demand. Training was largely handled by librarians who provided overviews of their subject areas, and focused most especially on databases and other resources to answer questions that were posed at the desks. The volunteer paraprofessionals were trained in a variety of subject areas and became important service providers at the reference desks.

In 2005, reference services were reorganized again by the library administration in an effort to become a more user-centered library and the merged reference department was entirely dissolved. The peer and tier reference model was retained, along with the service of the staff volunteers. Librarians, for their part, became part of discipline-based Subject Councils. Reference activities were overseen at that time by a new position called the "head of outreach." In addition, circulation and reference services were combined behind one central service desk in Anschutz and Watson Libraries, and student IT workers were assigned to work at the combined service desk to handle increasing amounts of technical-related questions.

\section{Feedback from Faculty and Students}

It can be seen, then, that between 2002 and 2005, the reference model at KU Libraries had changed from a traditional one, to one in a near constant state of evolution. These changes, despite the intentions behind them, ultimately proved not to meet the information needs of library users who expressed their concerns about service quality via a LibQUAL $+{ }^{\circledR}$ survey administered in 2006. As it turned out, faculty in particular desired the librarians to return to the reference desks to provide the specialized level of research assistance they and their students were so sorely missing. Comments by faculty were noteworthy in their support of a return to a more "traditional" reference model where staff, as opposed to students, served as the first point of contact at the public service desks. The 2006 LibQUAL $+{ }^{\circledR}$ survey also coincided with a nearly complete turnover in library administration and the arrival of a new dean of libraries.

Thus, in January 2007, under the direction of a new administration and a new reference coordinator, the peer and tier model was abandoned and KU librarians returned to staffing the desks in Anschutz and Watson Libraries. While undergraduate students no longer played a role at the reference desk, the reference volunteer staff was most definitely retained. In fact, a more formalized research specialists program was initiated that summer, based on the volunteers from other library units who had already been a part of the service since 2004. New recruits for the research specialists program were solicited as well. In addition, the previous practice of hiring graduate student assistants to work over the evening and weekend hours was resumed. Undergraduate student workers previously employed for reference services were refocused to serve the circulation department. 


\section{Current State}

Since 2007, even with no established "reference department" within the KU Libraries, reference services has come to rely on a core group of librarians, library staff from other units, and graduate student assistants to provide reference services at the combined reference and circulation desks. The cohort of staff who provide these services are housed in several library departments, including Research Services, Instructional Services, Collections, Preservation, Acquisitions, and Cataloging. In addition, the number of graduate students working evening and weekend hours in both Watson and Anschutz Libraries has been doubled. While the Watson reference and circulation services are still offered from one central service point, Anschutz Library was converted in 2009 to a "learning studio" environment, designed to accommodate student needs in a more comprehensive and holistic way. Part of that reconfiguration resulted in the establishment of a service island-a shared information desk—where staff from IT, reference, and Student Success now work in concert to identify and respond to a variety of student questions and make appropriate referrals.

Due to its past success, the research specialists program was reinforced and formalized as a way to continue to address staffing needs for the desks. Each volunteer was required to have supervisory permission and agree to a list of expectations for working at the desks, including the following:

- Commit to 4 hours of desk time each week.

- Attend all training sessions as scheduled.

- Attend the monthly reference/instruction meetings.

The table below depicts the total numbers of various staff and the hours worked per week at Anschutz and Watson Libraries from 2006 thru 2012. On average, the number of librarians has remained consistent at about 16 staff, as has the number of research specialists. However, the number of graduate student assistants has increased dramatically over the years as a result of staff reassignments and shifting schedule needs. In 2006, librarians generally worked at the reference desk six hours per week, and by 2012, averaged between two and four hours per week. Essentially librarians' time commitment for reference desk duties has been reduced by approximately 50\% (i.e., decreased from 80 hours to 42 hours per week between the two desks.)

Table. Reference Staffing Levels at Anschutz and Watson Desks, 2006-2012

\begin{tabular}{|l|r|r|r|r|r|r|r|r|}
\hline & $\mathbf{2 0 0 6}$ & & $\mathbf{2 0 0 8}$ & & $\mathbf{2 0 1 0}$ & & $\mathbf{2 0 1 2}$ & \\
\hline Staff Level & No. & Weekly Hr. & No. & Weekly Hr. & No. & Weekly Hr. & No. & Weekly Hr. \\
\hline Librarian & 15 & 80 & 18 & 80 & 16 & 52 & 15 & 42 \\
\hline Research Specialist & 14 & 102 & 17 & 96 & 16 & 84 & 15 & 56 \\
\hline Graduate Student & 5 & 35 & 4 & 33 & 5 & 40 & 9 & 60 \\
\hline \hline Total & 34 & 217 & 39 & 209 & 37 & 176 & 39 & 158 \\
\hline
\end{tabular}


Results from the LibQUAL $+{ }^{\circledR}$ survey in 2009 verified that library users saw an improvement in all services, including reference, since the previous 2006 LibQUAL $+{ }^{\circledR}$ survey. The research specialists program has proven to be very successful and the libraries' service desks could not have been staffed without them during the past few years. These staff members have become an integral part of the reference team and bring a strong set of skills and knowledge from their areas. They enjoy serving the public and using their own specialized skills (developed in cataloging or in interlibrary loan, for example), augmented by training, as a framework with which to answer questions. They also benefit from the diversity of responsibilities they gain as a result of volunteering, meet new staff, and learn about the various ways a complex organization aids faculty and students in the research and learning process. In addition, many of these staff have earned or are working on their graduate library degrees in the interest of furthering their library careers. This experience has aided several in attaining professional appointments at other institutions or libraries around the country.

\section{Conclusion}

The roles of academic librarians will continue to evolve, as will the staffing models to provide reference services. As practitioners and lifelong learners, librarians are accustomed to acquiring new skills on the job and accept that change is constant in their environment. For the last six years, the reference staffing model at KU Libraries has proved to be successful and relatively stable. The contributions of the paraprofessional research specialists have played an important role in achieving that success. As noted in the discussion above, the reference staffing model using paraprofessionals has been retained throughout a period of consistent change at KU Libraries. It has allowed the libraries to tap into expertise of non-reference staff and has aided in the development and implementation of other services, including chat and IM. Further, librarians have been able to use time formerly spent at the reference desk for other professional activities.

As users' modes of inquiry continue to evolve, the KU Libraries' model will adjust to accommodate them in a changing technological milieu. Several questions have arisen of late within the KU environment that will require further attention. For example, is it necessary to have librarians with very specialized skills working at a general reference and information desk? Furthermore, is it cost-effective to have librarians provide only in-depth research consultations from their offices, meeting with users who drop in or by appointments? Will online or virtual modes of communication supplant the notion of a physical "service desk" entirely in the near future? The bottom line is that reference services in academic libraries and at the University of Kansas Libraries will continue to evolve, but will only remain vital as long as libraries continue to adapt to users' changing research needs and learning styles.

(C) 2013 Frances Devlin and John Stratton

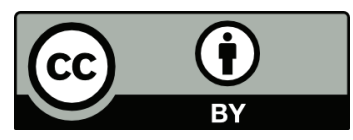


This article is licensed under a Creative Commons Attribution 3.0 Unported License. To view a copy of this license, visit http://creativecommons.org/licenses/by/3.0/.

To cite this report: Frances Devlin and John Stratton. "Evolving Models of Reference Staffing at the University of Kansas Libraries." Research Library Issues: A Report from ARL, CNI, and SPARC, no. 282 (2013). http://publications.arl.org/rli282/. 


\section{Research Library Issues}

\section{A Report from ARL, CNI, and SPARC}

Research Library Issues (RLI) focuses on current and emerging topics that are strategically important to research libraries. The articles explore issues, share information, pose critical questions, and provide examples. Ideas for articles are welcomed. Please send ideas to Sue Baughman, ARL Deputy Executive Director, sue@arl.org.

Association of Research Libraries

21 Dupont Circle, NW, Suite 800

Washington, DC 20036

P: 202-296-2296

F: 202-872-0884

ISSN 1947-4911

Executive Director: Elliott Shore

Editor: M. Sue Baughman

Assistant Editor: Kaylyn Groves

(C) 2013 Association of Research Libraries

ARL policy is to grant blanket permission to reprint as long as full attribution is made. Exceptions to this policy may be noted for certain articles. This is in addition to the rights provided under sections 107 and 108 of the Copyright Act. For more information, contact ARL Publications pubs@arl.org.

Current and back issues are available on the ARL Digital Publications website publications.arl.org/rli. The website is also where you may sign up for alerts to new releases of Research Library Issues. 